\title{
Phenological stages of the 'Paluma' guava tree in a region of subtropical climate according to the BBCH scale
}

\author{
Vanessa da Fontoura Custódio Monteiro ${ }^{1 *} \oplus$, Emerson Dias Gonçalves ${ }^{2} \oplus$, Pedro Henrique Abreu Moura²®, \\ Larissa Vieira da Silva ${ }^{3}$, Fabrina Bolzan Martins ${ }^{3}$, Paulo Márcio Norberto ${ }^{2}$ (1) \\ ${ }^{1}$ Universidade do Vale do Sapucaí, Unidade Fátima, Pouso Alegre, MG, Brasil. E-mail: vanfontoura@gmail.com \\ ${ }^{2}$ Empresa de Pesquisa Agropecuária de Minas Gerais, Maria da Fé, MG, Brasil. E-mail: emerson@epamig.br; pedrohamoura@epamig.br; paulonor@gmail.com \\ ${ }^{3}$ Universidade Federal de Itajubá, Instituto de Recursos Naturais, Itajubá, MG, Brasil. E-mail: larissa_vieira08@hotmail.com; fabrinabm@gmail.com
}

ABSTRACT: In the Serra da Mantiqueira region, of subtropical altitude climate, the cultivation of guava is geared towards subsistence farming. In this region, there is still no description of the phenological cycle of the guava tree or the definition of the most appropriate fructification pruning times. Therefore, the objective of this study was to characterize the phenology of the reproductive development of the guava tree from the cultivar Paluma in two times of fructification pruning (June and August) and to determine the degree-days requirements of the cultivar under the conditions of subtropical altitude climate. Through the BBCH general scale associated with the traditional Fleckinger's code, it was possible to observe the duration of the different phenological stages. The duration of the phenological cycle from pruning to fruit harvest was 249 days for plants pruned in June and 224 days for pruned plants in August. The heat unit accumulation from B1:01 to J:81 did not vary significantly between the pruning times. Plant pruning in August allows early flowering and a shorter phenological cycle.

Key words: degree-days; fructification pruning; phenology; Psidium guajava

\section{Estágios fenológicos da goiabeira 'Paluma' em região de clima subtropical de acordo com a escala BBCH}

RESUMO: Na região da Serra da Mantiqueira, onde ocorre o clima subtropical de altitude, o cultivo da goiaba é voltado para a agricultura de subsistência. Nesta região, ainda não há uma descrição do ciclo fenológico da goiabeira nem a definição das épocas de poda de frutificação mais adequadas. Portanto, o objetivo do estudo foi caracterizar a fenologia do desenvolvimento reprodutivo da goiabeira da cultivar Paluma em duas épocas de poda de frutificação (junho e agosto) e determinar as exigências de graus-dia da cultivar nas condições de clima subtropical de altitude. Por meio da escala geral BBCH associada ao código de Fleckinger tradicional, foi possível observar a duração dos diferentes estágios fenológicos. A duração do ciclo fenológico, da poda à colheita dos frutos, foi de 249 dias para as plantas podadas em junho e de 224 dias para as plantas podadas em agosto. O acúmulo de unidades de calor de B1:01 a J:81 não variou significativamente entre as épocas de poda. A poda das plantas em agosto proporciona floração precoce e ciclo fenológico mais curto.

Palavras-chave: graus-dia; poda de frutificação; fenologia; Psidium guajava

\footnotetext{
* Vanessa da Fontoura Custódio Monteiro - E-mail: vanfontoura@gmail.com (Corresponding author)

Associate Editor: Sérgio Ruffo Roberto
} 


\section{Introduction}

The guava tree (Psidium guajava L.) belongs to the Myrtaceae family and is native to the central region of the American continent (Singh, 2018; Silva et al., 2020). Due to its ability to adapt to different edaphoclimatic conditions, the guava species is cultivated in different locations around the world (Salazar et al., 2006). Brazil is the world's $7^{\text {th }}$ largest guava fruit producer, followed by India, Indonesia, China, Mexico, Pakistan, and Malawi (FAO, 2019).

In Brazil, guava is mainly cultivated in the northeast and southeast regions, where the tropical climate predominates (Alvares et al., 2013). The main guava fruit producing states are Pernambuco and São Paulo, with 210,512 and 194,002 tons produced per year, respectively (IBGE, 2019). Among the most cultivated, the cultivar (cv.) Paluma is very popular among producers because it is vigorous, highly productive, and has fruits with characteristics desired both for processing (e.g., sweets, juices, and jams) and fresh consumption.

With this expressive production in the country, commercial cultivation also occurs in some areas of subtropical climate, such as in the municipality of Valinhos, Taquaritinga, Vista Alegre do Alto, and Monte Alto in the interior of São Paulo state (Landau et al., 2020), and in the region of Campo das Vertentes in Minas Gerais state (IBGE, 2019). In the south of the Campo das Vertentes is located the Serra da Mantiqueira, which includes parts of southern Minas Gerais and the states of São Paulo and Rio de Janeiro, where the subtropical altitude climate occurs (Martins et al., 2018). In municipalities located in this mountainous chain, the production of guavas is not very significant due to the lower minimum air temperatures, being cultivated essentially by small producers who work its production as a form of subsistence farming. Therefore, there is no definition of the pruning times most appropriate to the climatic conditions of the region.

In Brazil, the largest volume of guava fruit sold is between January and April, due to the normal harvest season of the crop (Serrano et al., 2008a). However, it is possible to plan the harvest for any month of the year through the management of fructification pruning (Ramos et al., 2011; Carballosa De la Paz et al., 2019).

Fructification pruning can be continuous or drastic. Continuous pruning is carried out on parts of the plant, focusing specifically on the branches that have already produced the fruits. This pruning results in several phenological stages simultaneously, making it difficult to manage the orchard. In drastic pruning, the shortening of the branches is carried out simultaneously in the entire plant. In this case, the phenological stages are more uniform, resulting in a concentration of the harvest in a given period and facilitating management actions during the production cycle (Santos et al., 2019).

Therefore, in order to determine the phenological stages of $P$. guajava, one must choose an appropriate phenological scale for the specie and evaluate its performance under field conditions (Uhlmann et al., 2017). Additionally, it is important to quantify the physiological time necessary to reach the development stages and, consequently, to determine the exact moment of the occurrence of the phenological stages, through the concept of degree-days (으 day), (Ferreira et al., 2019). The Biologische Bundesanstalt, Bundessortenamt und Chemische Industrie ( $\mathrm{BBCH}$ ) scale has been used worldwide in several agricultural crops in order to have a standardized description of the phenological stages (Mendes et al., 2017) and has greater efficiency in quantifying the heat unit accumulation necessary to reach each stage of development.

Several studies have been conducted in different Brazilian regions seeking to assess the influences of pruning times on the phenological cycle of the guava tree (e.g., Hojo et al., 2007; Serrano et al., 2008 a, b, c; Ramos et al., 2011). However, there is no consistent information for regions with subtropical altitude climate, as in Serra da Mantiqueira, neither is there a clear definition of the best time for pruning. Furthermore, to the best of our knowledge, the $\mathrm{BBCH}$ general scale has not been used in any of the Brazilian studies. This paper approaches these knowledge gaps by using the $\mathrm{BBCH}$ scale to describe the phenological stages of the guava tree cv. Paluma in two pruning times (June and August), and determine the degree-days under the conditions of altitude subtropical climate in Brazil.

\section{Materials and Methods}

The study was carried out in an experimental orchard located at the Empresa de Pesquisa Agropecuária de Minas Gerais (EPAMIG), Maria da Fé, South of Minas Gerais, Brazil $\left(22^{\circ} 19^{\prime} 01^{\prime \prime} \mathrm{S}\right.$ and $45^{\circ} 22^{\prime} 31^{\prime \prime} \mathrm{W}$, altitude of $\left.1332 \mathrm{~m}\right)$. The climate according to the Köppen classification is Cwb - subtropical in altitude, with dry winter and rainy summer with mild temperatures (Martins et al., 2018).

Daily temperature and rainfall data were recorded during the experimental period (2017-2018), which corresponded to the two times of fructification pruning: June and August (Figure 1).

The 'Paluma' guava orchard was implanted in October 2008 and plants were cultivated at a spacing of $7.0 \times 5.0 \mathrm{~m}$, without an irrigation system. All cultural practices typically recommended for guava tree cultivation were performed.

The experimental design used was randomized blocks, with 10 blocks and two treatments: pruning time 1 (24 June 2017) and pruning time 2 (26 August 2017), evaluating 2 plants per block. In each plant, 4 branches were marked, one in each quadrant of the canopy (north, south, east and east west) to accompany the development of the phenological phases, totaling 80 branches. The pruning intensity was medium (branches pruned to $1 / 3$ of its length, from the base), and all plant growth branches were pruned without considering their diameter (Serrano et al., 2008a).

The phenological stages were evaluated two to four times a week, defined according to the traditional nomenclature of Fleckinger (1945) associated with the $\mathrm{BBCH}$ general 


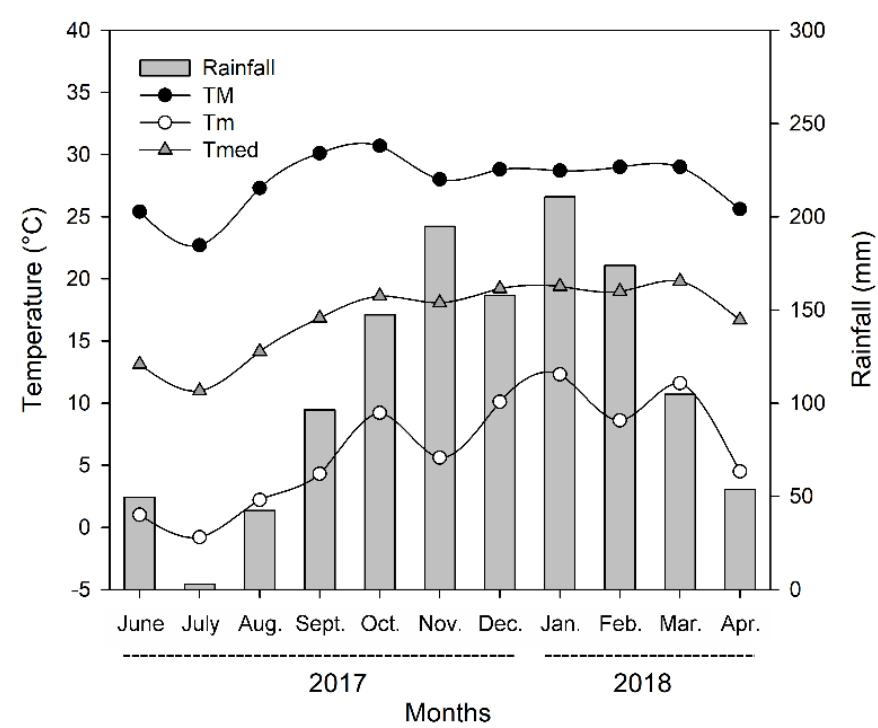

Figure 1. Monthly values of temperature $(T M=$ maximum air temperature, $\mathrm{Tm}=$ minimum air temperature, $\mathrm{Tmed}=$ medium air temperature $\left.-{ }^{\circ} \mathrm{C}\right)$ and rainfall $(\mathrm{mm})$ recorded during the study period at the automatic weather station of the Instituto Nacional de Meteorologia (INMET) (22 $18^{\prime} 52.44^{\prime \prime} S$ and $45^{\circ} 22^{\prime} 22.97^{\prime \prime} \mathrm{W}$; altitude of $1281 \mathrm{~m})$. EPAMIG, Maria da Fé, MG, Brazil.

scale described by Salazar et al. (2006) (Table 1). This scale identifies different developmental stages by a two digit code. The first digit refers to major stages using values between zero and nine; the second digit, also scaled from zero to nine and relates to its secondary stages. (Salazar et al., 2006).

In this study, the duration of stages A:00 and K:89 was not evaluated because, after the pruning, plants already had shoots in A:00 which were marked for monitoring development and fruit harvest was carried out at the transition from stage $\mathrm{J}: 81$ to $\mathrm{K}: 89$.

To quantify the heat unit requirements, and consequently, to determine the exact moment of the occurrence of the stages of reproductive development of the guava tree, we used the concept of degree-days (GDD, ${ }^{\circ} \mathrm{C}$ day), given by Ferreira et al. (2019) and Martins et al. (2019) (Equation 1).

$$
\mathrm{GDD}=\sum_{\mathrm{i}=1}^{\mathrm{n}} \mathrm{Tmed}-\mathrm{Tb}, \text { if } \mathrm{Tmed}<\mathrm{Tb}, \text { Tmed }=\mathrm{Tb}
$$

where: GDD = Growing degree-days $\left({ }^{\circ} \mathrm{C}\right.$ day $) ; \mathrm{Tmed}=$ medium air temperature $\left({ }^{\circ} \mathrm{C}\right)$, obtained by the arithmetic mean data from the automatic weather station (Figure 1); $\mathrm{Tb}=$ base temperature $\left(12^{\circ} \mathrm{C}\right.$ ) (Salazar et al. 2006); i = start date of the development stage; $\mathrm{n}=$ end date of the development stage, both considering the dates of occurrence of the $\mathrm{BBCH}$ general scale (Table 1).

This method of heat unit accumulation considers the medium air temperature and the cardinal base temperature (Tb), below which development does not occur (Martins et al., 2019; Silva et al., 2020).

Data were tested for normality (Shapiro-Wilk test) and variance homogeneity (Levene's test). The duration in days and degree-days between pruning times was compared by t-test (parametric) and Mann-Whitney U-test (nonparametric). The significant difference was established for all cases at $p<0.05$. Both analyses were performed in SigmaPlot software, version 11.0 (Systat Software, Inc.).

\section{Results and Discussion}

The use of the $\mathrm{BBCH}$ general scale associated with the traditional Fleckinger's code (1945) provided a coherent visual description of the different stages of development of the $\mathrm{cv}$. Paluma from the formation of a new bud $(A: 00)$ to fruit ripening ( $\mathrm{K}: 89)$, (Figure 2). Using the $\mathrm{BBCH}$ scale, it was possible to identify the moment of occurrence from B1:01 to $\mathrm{J}: 81$ of the guava tree in both pruning times (June and August).

Table 1. Description BBCH general scale and the traditional Fleckinger's code of Psidium guajava L., described by Salazar et al. (2006).

\begin{tabular}{cl}
\hline Phenological codes & \multicolumn{1}{c}{ Description } \\
\hline A:00 & Winter bud. The bud is greenish brown and completely closed. It is closely linked to the twig. \\
B1:01 & Bud swelling. The bud swells and becomes greenish. \\
B2:02 & Bud growth begins. The bud gets longer, and scales start opening. \\
C:11 & First leaves sprouting. The first leaf appears and becomes visible. \\
D2:15 & More leaves unfolded. Not yet at full size. \\
E1:51 & Leaves completely developed. Leaf growth completed. \\
E2:55 & Appearance of flower buds. Calyx becomes visible.Internode lengthening stops. \\
E3:57 & Flower buds visible. Sepals still closed. \\
E5:59 & Sepals totally open. Sepals fully extended so that petals can open. \\
F:65 & Full flowering. At least 50\% of flowers open. First petals falling. \\
G:67 & Petal fall. Flowers fading and most petals collapse. \\
H1:71 & Fruit setting. Fruit size up to 10 mm. \\
I1:78 & Fruit growth. Fruit increase up to 80\% of final size. \\
J:81 & Fruit scolour changing. Beginning of ripening; fruit reaching its final volume.Colour changing from green to \\
K:89 & yellowish pale green. \\
\hline & Fruit ripening. Fruit reached final volume and becomecompletely yellow. Releasing pleasant aroma, and \\
\hline
\end{tabular}




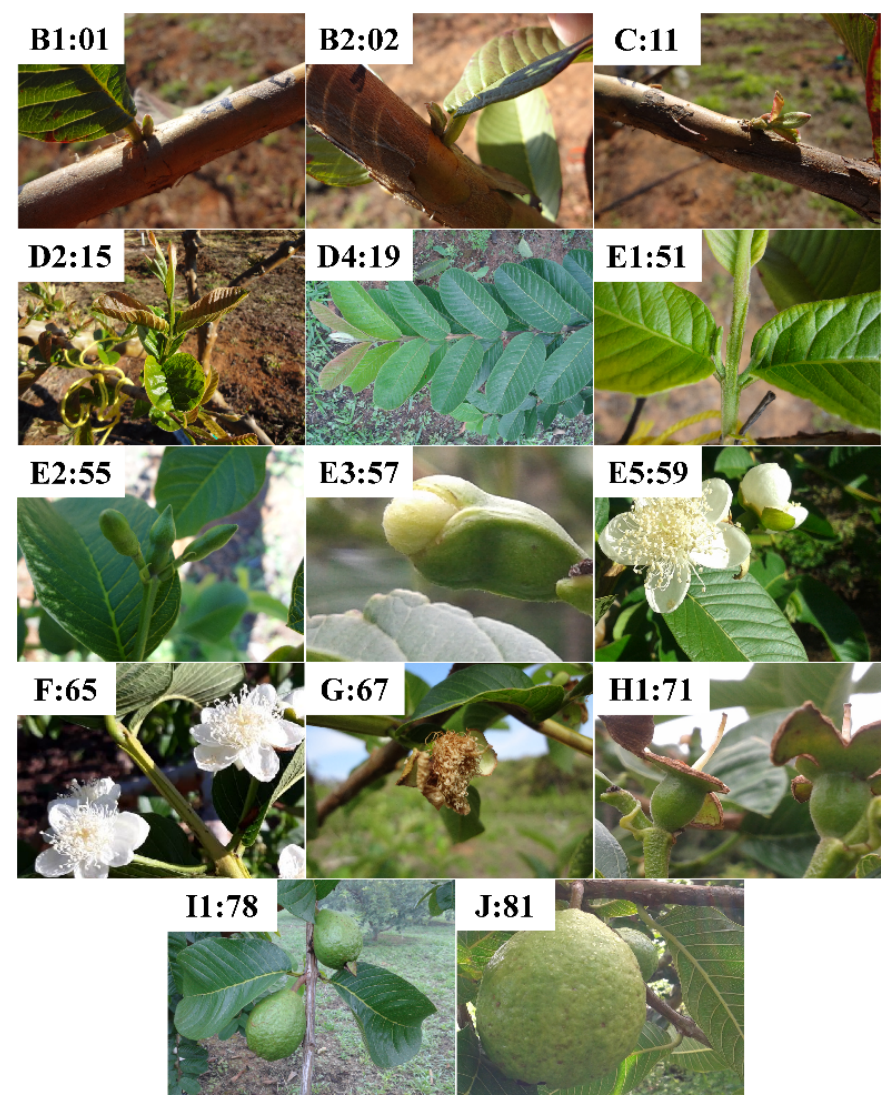

Figure 2. Phenological stages according to the $\mathrm{BBCH}$ general scale and the traditional Fleckinger's code observed in Psidium guajava L. EPAMIG, Maria da Fé, MG, Brazil.

The beginning of $\mathrm{B} 1: 01$ varied between the pruning times and in the same plant. In guava trees pruned in June (pruning time 1), B1:01 appeared between 1 and 40 days after pruning, with greater occurrences on the first and 17th days. In plants pruned in August (pruning time 2), B1:01 appeared between 2 and 20 days, with a higher occurrence in $50 \%$ of the evaluated shoots about 20 days after pruning.

Most of the phenological stages had a significantly different duration, in days ( $p<0.05$ ), between the two pruning times. In general, the stages were more extensive in pruning time 1 (June), except for $F: 65$ and $G: 67$, which were more extensive in pruning time 2 (August). Only B2:02, D2:15, E3:57, and H1:71 were statistically similar between June and August (Table 2).

Despite the increase in the number of days and the increase of B1:01 ( 14 days) in the plants pruned in June (Table 2), the heat unit accumulation was lower (Table 3). This is likely explained by the higher frequency (19 days) of medium air temperature below $12^{\circ} \mathrm{C}(\mathrm{Tb})$ between June and in early August. This lower accumulation of degree-days is also observed from B2:02 to D4:19 in pruning time 1, which also develops in periods with a higher frequency of Tmed $<\mathrm{Tb}$, consequently decreasing metabolic processes (Ferreira et al. 2019). However the duration (in days) did not vary significantly $(p<0.05)$ in B2:02 and D2:15 between the two pruning times (Table 2). At pruning time 2 , there was no record of Tmed $<\mathrm{Tb}$ (Figure 1).
Table 2. Duration (days) of phenological stages of 'Paluma' guava tree in two pruning times (1- June pruning, 2- August pruning) according to the $\mathrm{BBCH}$ general scale and the traditional Fleckinger's code. EPAMIG, Maria da Fé, MG, Brazil.

\begin{tabular}{ccc}
\hline \multirow{2}{*}{ Phenological codes } & \multicolumn{2}{c}{ Duration (days) } \\
\cline { 2 - 3 } & 1- June pruning & 2- August pruning \\
\hline A:00 & - & - \\
B1:01 & $17.1 \pm 0.6 a^{*}$ & $3.0 \pm 0.1 b^{*}$ \\
B2:02 & $6.0 \pm 0.1 a^{*}$ & $6.3 \pm 0.0 a^{*}$ \\
C:11 & $6.1 \pm 0.1 \mathrm{a}$ & $5.6 \pm 0.1 \mathrm{~b}$ \\
D2:15 & $5.2 \pm 0.1 \mathrm{a}^{*}$ & $5.4 \pm 0.0 \mathrm{a}^{*}$ \\
D4:19 & $6.7 \pm 0.1 \mathrm{a}^{*}$ & $6.3 \pm 0.0 \mathrm{~b}^{*}$ \\
E1:51 & $3.6 \pm 0.0 \mathrm{a}^{*}$ & $2.9 \pm 0.0 \mathrm{~b}^{*}$ \\
E2:55 & $54.0 \pm 3.4 \mathrm{a}^{*}$ & $44.6 \pm 0.5 \mathrm{~b}^{*}$ \\
E3:57 & $10.6 \pm 0.3 \mathrm{a}^{*}$ & $10.3 \pm 0.0 \mathrm{a}^{*}$ \\
E5:59 & $6.5 \pm 0.0 \mathrm{a}^{*}$ & $6.1 \pm 0.0 \mathrm{~b}^{*}$ \\
F:65 & $2.6 \pm 0.0 \mathrm{~b}$ & $2.8 \pm 0.0 \mathrm{a}$ \\
G:67 & $2.1 \pm 0.0 \mathrm{~b}^{*}$ & $2.3 \pm 0.0 \mathrm{a}^{*}$ \\
H1:71 & $2.3 \pm 0.0 \mathrm{a}^{*}$ & $2.3 \pm 0.0 \mathrm{a}^{*}$ \\
I1:78 & $109.0 \pm 0.1 \mathrm{a}^{*}$ & $90.8 \pm 0.1 \mathrm{~b}^{*}$ \\
J:81 & $5.6 \pm 0.0 \mathrm{a}^{*}$ & $5.3 \pm 0.0 \mathrm{~b}^{*}$ \\
K:89 & - & - \\
B1:01 to J:81 & $237.2 \pm 3.9 \mathrm{a}^{*}$ & $194.6 \pm 0.8 \mathrm{~b}^{*}$ \\
\hline
\end{tabular}

Values followed by same letter in the same line do not show significant differences according to t-test and Mann-Whitney U-test* $(p \geq 0.05)$. Values are presented as means \pm standard error.

Table 3. Degree-days (GDD, ${ }^{\circ} \mathrm{C}$ day) of phenological stages of 'Paluma' guava tree in two pruning times (1- June pruning, 2- August pruning) according to the $\mathrm{BBCH}$ general scale and the traditional Fleckinger's code. EPAMIG, Maria da Fé, MG, Brazil.

\begin{tabular}{ccc}
\hline \multirow{2}{*}{ Phenological codes } & \multicolumn{2}{c}{ Duration (GDD, ${ }^{\circ} \mathrm{C}$ day) } \\
\cline { 2 - 3 } & 1- June pruning & 2- August pruning \\
\hline A:00 & - & - \\
B1:01 & $14.6 \pm 0.4 \mathrm{~b}$ & $20.2 \pm 0.6 \mathrm{a}$ \\
B2:02 & $6.6 \pm 0.4 \mathrm{~b}$ & $37.5 \pm 0.7 \mathrm{a}$ \\
C:11 & $18.9 \pm 1.5 \mathrm{~b}$ & $39.4 \pm 0.9 \mathrm{a}$ \\
D2:15 & $10.5 \pm 0.6 \mathrm{~b}^{*}$ & $37.7 \pm 0.2 \mathrm{a}^{*}$ \\
D4:19 & $19.5 \pm 0.9 \mathrm{~b}^{*}$ & $53.2 \pm 1.5 \mathrm{a}^{*}$ \\
E1:51 & $18.9 \pm 0.3 \mathrm{~b}^{*}$ & $24.8 \pm 1.0 \mathrm{a}^{*}$ \\
E2:55 & $308.1 \pm 25.7 \mathrm{a}^{*}$ & $311.3 \pm 4.2 \mathrm{a}^{*}$ \\
E3:57 & $83.7 \pm 2.5 \mathrm{a}^{*}$ & $84.6 \pm 0.5 \mathrm{a}^{*}$ \\
E5:59 & $46.8 \pm 1.4 \mathrm{~b}$ & $51.4 \pm 0.7 \mathrm{a}$ \\
F:65 & $24.9 \pm 0.1 \mathrm{~b}$ & $30.5 \pm 0.3 \mathrm{a}$ \\
G:67 & $20.3 \pm 0.2 \mathrm{~b}^{*}$ & $27.1 \pm 0.2 \mathrm{a}^{*}$ \\
H1:71 & $21.5 \pm 0.4 \mathrm{~b}^{*}$ & $27.0 \pm 0.2 \mathrm{a}^{*}$ \\
I1:78 & $844.1 \pm 0.4 \mathrm{a}^{*}$ & $757.3 \pm 1.1 \mathrm{~b}^{*}$ \\
J:81 & $51.8 \pm 0.4 \mathrm{a}^{*}$ & $46.7 \pm 0.3 \mathrm{~b}^{*}$ \\
K:89 & - & - \\
\hline & Cumulative GDD ( ${ }^{\circ} \mathrm{C}$ day) \\
B1:01 to J:81 & $1490.9 \pm 29.0 \mathrm{a}^{*}$ & $1549.4 \pm 4.8 \mathrm{a}^{*}$ \\
\hline
\end{tabular}

Values followed by same letter in the same line do not show significant differences according to t-test and Mann-Whitney U-test* $(p \geq 0.05)$. Values are presented as means \pm standard error.

Regarding the degree-days requirement of each phenological stage, we observed that the degree-days were lower from B1:01 to E1:51 and from E5:59 to $\mathrm{H1:71}$ in pruned guava trees in June (average $=89.2^{\circ} \mathrm{C}$ day and $113.7^{\circ} \mathrm{C}$ day, respectively) in relation to guava trees pruned in August 
(average $=213.1^{\circ} \mathrm{C}$ day and $136.1^{\circ} \mathrm{C}$ day, respectively). The contrary was observed from I1:78 to J:81, with greater heat unit accumulation in pruning time 1 (mean $=896.0^{\circ} \mathrm{C}$ day) compared to pruning time 2 (mean $=804.0^{\circ} \mathrm{C}$ day). Stages E2:55 and E3:57 did not differ in degree-days accumulation between pruning times (Table 3 ). There was no significant difference $(p<0.05$ ) between accumulated degree-days (DD) from stage B1:01 to J:81 between plants pruned in June $\left(1490.9^{\circ} \mathrm{C}\right.$ day) and in August $\left(1549.4^{\circ} \mathrm{C}\right.$ day), (Table 3; Figure 3AC).

There was a difference between the weather conditions (temperature and rainfall) during the two pruning times. During the evaluation period of the phenological cycle in pruning time 1 (June), the maximum, minimum, and medium absolute temperatures of the air ranged between 26.0 to $30.7^{\circ} \mathrm{C} ;-0.8$ to $11.7^{\circ} \mathrm{C}$; and 12.6 to $19.8^{\circ} \mathrm{C}$, respectively (Figure $3 \mathrm{~A}$ ). In pruning time 2 (August), the maximum temperature ranged from 28.0 to $30.7^{\circ} \mathrm{C}$; minimum: 4.3 to $10.6^{\circ} \mathrm{C}$; and medium: 17.2 to $20.0^{\circ} \mathrm{C}$ (Figure $3 \mathrm{C}$ ). However, in general we observed the existence of an inverse relationship between the duration of each stage and the medium air temperature. This means that the lower (higher) the air temperature, the higher (lower) the average duration of each phenological stage.

In pruned plants in June, stages from B1:01 to E1:51 were marked by rainfall index below $100 \mathrm{~mm}$, whereas in B1:01 the index was only $4.2 \mathrm{~mm}$. On the contrary, there was greater rainfall during stages $11: 78$, E3:57, E2:55, and J:81, with 841.0, 399.4, 297.4 and $225 \mathrm{~mm}$, respectively (Figure 3B). During pruning time 2 , there was less rainfall $(0.2 \mathrm{~mm})$ only during stages B1:01 and B2:02, while in stages $11: 78$ there was greater accumulated rainfall $(635.2 \mathrm{~mm})$, followed by $\mathrm{E}: 55$ (322.8 $\mathrm{mm}$ ), $\mathrm{H1:71}$ (222.0 mm), and E3:57 (215.8 mm), (Figure 3D).

The lowest accumulation of degree-days in stages $\mathrm{E} 1: 51, \mathrm{E} 5: 59, \mathrm{~F}: 65, \mathrm{G}: 67$, and $\mathrm{H} 1: 71$ in pruning time 1 (Table 3 ) is not related to Tmed < Tb because this condition did not occur during the guava development period (August to
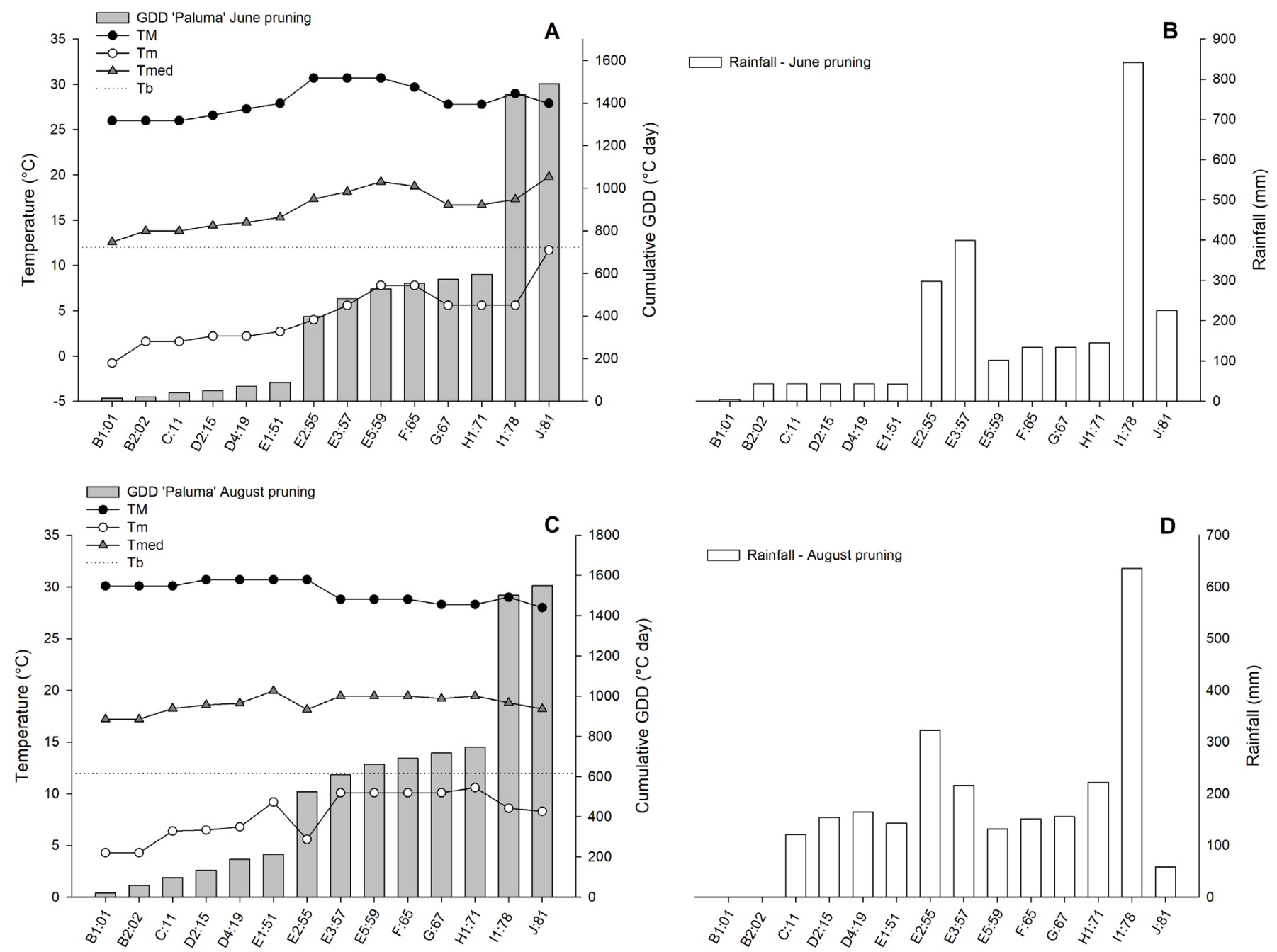

Phenological codes

Figure 3. Cumulative degree-days - GDD ( ${ }^{\circ} \mathrm{C}$ day) of phenological stages of 'Paluma' guava tree in two pruning times (A: June, C: August). The air temperatures (TM = maximum air temperature, $\mathrm{Tm}=$ minimum air temperature, $\mathrm{Tmed}=\mathrm{medium}$ air temperature $-{ }^{\circ} \mathrm{C}$ ) during the phenological stages and base temperature of guava $\left(\mathrm{Tb}-{ }^{\circ} \mathrm{C}\right)$ are shown in $\mathrm{A}$ and $\mathrm{C}$. The rainfall $(\mathrm{mm})$ during the periods is shown in B and D. EPAMIG, Maria da Fé, MG, Brazil. 
November; Figure 1). This response is possibly related to the low values of minimum air temperature (ranging from $2.7^{\circ} \mathrm{C}$ to $7.8^{\circ} \mathrm{C}$ ) that occurred during the time of the stages (Figure 3A). In pruning time 2 (August), these stages took place between late September and early January, when the minimum air temperature ranged from $9.2^{\circ} \mathrm{C}$ to $10.6^{\circ} \mathrm{C}$ (Figures 1 and 3C).

In addition to the influence of air temperature, the phenological stages need sufficient amounts of water and nutrients for optimal development. The consumption of water by the guava tree is variable between the phenological stages. The lack of water in the soil, especially in times of intense vegetative growth, flowering, modification, and fruit development can result in a decrease in production (Manica et al., 2000). The delay (in days) of E1:51, E2:55, and E3:59 in pruning time 1 (Table 2) occurred due to the decrease in rainfall compared to pruning time 2 (Figure 3BD). On the other hand, the total rainfall of $134 \mathrm{~mm}$ (Figure $3 B$ ) was sufficient to promote a faster development (in days) of F:65 and G:67 in pruning time 1 (Table 2).

The heat unit accumulation, via the degree-day method, facilitates comparisons among studies at different times and geographic areas. The 63-day interval between the two pruning times did not result in a significant difference $(p<$ 0.05 ) in the total accumulation of degree-days from B1:01 to $\mathrm{J}: 81$ (Table 3). The values obtained are close to those found by Salazar et al. (2006) for the Ruby guava cultivar in Denia (Alicante, Spain). On the other hand, Singh et al. (2015), in Lucknow, India, observed that the duration (in days and degree-days) of the phenological stages of guava cv. Lalit varied in different pruning times and without pruning.

The total cycle (in days) from pruning to concentrated fruit harvest was 249 days for guava trees pruned in June, and 224 days for trees pruned in August. In plants of pruning time 1, the pruning cycles to full flowering (F:65), from pruning to the end of flowering (G:67) and from full flowering to the beginning of fruit ripening (J:81) of most evaluated shoots were 121,144 , and 114 days, respectively. In plants of pruning time 2, the same cycles were 115 (full flowering), 133 (from pruning to the end of flowering), and 87 days (full flowering to the beginning of fruit ripening) (Table 4).

In Brazil, where the phenological studies of the guava tree are evaluated using the civil calendar, Ramos et al. (2011) observed shorter cycles (from pruning to fruit harvest) for cv. Paluma when grown without an irrigation system. This study occurred in Botucatu, Sao Paulo, which has a Cfa climate (humid subtropical climate with hot summer) compared to our study (Table 4). These authors observed that the duration of this cycle was 154 days for guava trees under no pruning treatment, and 234 and 151 days for plants pruned in June and August, respectively. In tropical climate conditions, for the cultivar Paluma in Pedro Canário, Espirito Santo, Serrano et al. (2008c) verified a cycle of 182 days (pruning in November and December) to 203 days (pruning in February), also observing that the cycle starts earlier in a period of higher air temperature.

Phenology is mostly influenced by air temperature conditions and not just the days of the civil calendar (Martins et al., 2019). Air temperature is important because it influences cell physiology. For example, it influences cell enzymatic activity, fluidity of membranes and conformation of proteins which compromise photosynthesis and respiration, acting directly on plant growth, development, and productivity (Ruelland \& Zachowski, 2010).

Although the use of thermal sum calculation methods is essential in phenological studies, their use in studies with Psidium guajava is almost non-existent, having been verified in few studies, such as Salazar et al. (2006) and Singh et al. (2015). Recently, in Brazil, Ferreira et al. (2019) estimated the cardinal temperatures for guava in the seedling phase, obtaining base temperature of 10.9 으, optimum of $17.3^{\circ} \mathrm{C}$, and maximum temperature of $51.2^{\circ} \mathrm{C}$. Although this information is scarce for the guava tree, it is important to determine the needs of the species under different weather conditions and their adaptations to climatic conditions for cultivation (Ferreira et al., 2019).

The guava tree has an immediate response to fructification pruning, since it is a technique that provides more sunlight to the tree canopies, which positively influences vegetative growth, photosynthesis efficiency, floral initiation, in addition to the quality and production of fruits (Singh \& Singh, 2007; Carballosa De la Paz et al., 2019). Therefore, the greater the accumulation of degree-days, the faster the buds appear and the shorter the time for flowering to occur, which was observed in pruning time 2 , when the plants accumulated more degree-days from B1:01 to F:65 (Table 3). Consequently, those plants presented a shorter duration (in days) of the pruning cycle to full flowering (Table 4).

The cultivation of guava in a non-irrigated management system requires the producer to correctly plan fructification pruning in order to avoid periods not only of low temperatures, but also periods of drought, especially during flowering and fruiting. The scarcity of water at these stages affects physiological processes, decreasing photosynthetic

Table 4. Phenological cycle of 'Paluma' guava tree in two pruning times (1- June pruning, 2- August pruning). EPAMIG, Maria da Fé, MG, Brazil.

\begin{tabular}{lcc}
\hline \multicolumn{1}{c}{ Phenological cycle } & \multicolumn{2}{c}{ Duration (days) } \\
\cline { 2 - 3 } & 1- June pruning & 2- August pruning \\
\hline Total cycle (from pruning to fruit harvest) & 249 & 224 \\
From pruning to full flowering & 121 & 115 \\
From pruning to the end of flowering & 144 & 133 \\
From full flowering to beginning of fruit ripening & 114 & 87 \\
\hline
\end{tabular}


assimilation, which consequently influences in lower allocation of photosynthes to fruits.

The development of 11:78 was marked by good water availability in the two pruning times (Figure 3BD). In pruning time 1 (June), this stage appeared between October to March, with greater occurrences of rainfall (Figure 1), which slightly delayed the fruit growth process and the transition to J: 81 (Tables 2 and 3).

Water availability is an important variable in fruit growth as already reported by Serrano et al. (2008c), who observed fruits of greater length and diameter of 'Paluma' guava trees in irrigated cultivation. Hojo et al. (2007) also found shorter flowering and maturation cycles of cv. Pedro Sato in times of higher medium air temperatures and higher levels of rainfall.

In areas of subtropical altitude climate, such as Maria da Fé - Brazil, rains occur more frequently and intensely from October to March. However, choosing the month to prune aiming at harvesting fruits must be well planned because in these areas the air temperature is very low in autumn and winter and present higher frequencies of Tmed $<\mathrm{Tb}$. In addition, in high altitude regions in the Serra da Mantiqueira, frost is a common climatic risk for the guava culture. Therefore, the producer must also analyze the topoclimatic factors of the location before starting a guava orchard in these regions.

Once the phenological stages are clearly identified, it gets easier to determination the the correct time for the application of cultural treatments (Salazar et al. 2006). In addition, the phenological characterization provides the fruit producer with the basic knowledge for planning likely dates for harvest (Hojo et al., 2007).

In this way, the $\mathrm{BBCH}$ general scale associated with the traditional Fleckinger's code for guava trees is an important and detailed tool for describing the occurrence of a phenological stage. The association of both methods allows the adoption of fructification pruning in strategic periods to decrease production expenses and provide greater fruit production and quality (Singh et al., 2015). This study is a pioneer in using the $\mathrm{BBCH}$ scale in Psidium guajava cv. Paluma in Brazil. It is noteworthy that further studies using this scale should be expanded to other species because it is a tool that contributes to the unification of research systems in agriculture.

\section{Conclusions}

The use of the $\mathrm{BBCH}$ scale and the determination of the degree-days requirement allowed a precise description of the phenological stages of 'Paluma' guava tree in a pioneering study in Brazil.

The higher frequency of Tmed $<T b$ during winter in the study region caused a delay mainly in the initial phenological stages of plants pruned in June, which extended the total cycle (from pruning to fruit harvest).

The fructification pruning carried out in August provided the development of phenological stages in climatic conditions more favorable to the species, shortening the total cycle.

\section{Compliance with Ethical Standards}

Author contributions: Conceptualization: EDG, VFCM, PHAM, PMN; Formal analysis: VFCM, LVS, EDG; Investigation: VFCM, EDG, PHAM, LVS; Writing - original draft: VFCM, EDG, PHAM, LVS, FBM; Writing - review \& editing: VFCM, EDG, PHAM.

Conflict of interest: The authors declare that they have no conflict of interest.

Financing source: This study was supported by the Fundação de Amparo à Pesquisa do Estado de Minas Gerais (FAPEMIG) [Grant Number APQ-00174-15].

\section{Literature Cited}

Alvares, C.A.; Stape, J.L.; Sentelhas, P.C.; Gonçalves, J.L.M.; Sparovek, G. Köppen's climate classification map for Brazil. Meteorologische Zeitschrift, v.22, n.6, p.711-728, 2013. https:// doi.org/10.1127/0941-2948/2013/0507.

Carballosa De la Paz, A.V.; Espinosa, B.G.G.; Brizuela, E.I.L.; Bravo, E.L.; Cueto, O.G. Fructification pruning in guava Crop (Psidium guajava L.) and its influence on yield. Revista Ciencias Técnicas Agropecuarias, v.28, n.4, p.81-88, 2019. https://revistas.unah. edu.cu/index.php/rcta/article/view/1191. 07 Dec. 2020.

Da Silva, F.A.; Viana, A.P.; Corrêa, C.C.G.; Carvalho, B.M.; Sousa, C.M.B.; Amaral, B.D.; Ambrósio, M.; Glória, L.S. Impact of Bayesian Inference on the Selection of Psidium guajava. Scientific Reports, v.10, e1999, 2020. https://doi.org/10.1038/s41598-020-58850-6.

Food and Agriculture Organization of the United Nations - FAO. FAOSTAT 2019. http://www.fao.org/faostat/en/\#rankings/ countries_by_commodity. 26 Dec. 2020.

Ferreira, M.C.; Martins, F.B.; Florêncio, G.W.L.; Pasin, L.A.A.P. Cardinal temperatures and modeling of vegetative development in guava. Revista Brasileira de Engenharia Agrícola e Ambiental, v.23, n.11, p.819-825, 2019. https://doi.org/10.1590/1807-1929/agriambi. v23n11p819-825.

Fleckinger, J. Notations phénologiques et représentations graphiques du développment des bourgeons de Poirier. In: C.R. Congrès de Paris de l'Association française pour l'avancement des Sciencies. Bibliographical reference in "Fruticultura de Coutanceau". 1971. Barcelona: Oikos-tau, 1945. 118p.

Hojo R.H.; Chalfun, N.N.J.; Hojo, E.T.D.; Souza, H.A.; Paglis, C.M.; São José, A.R. Caracterização fenológica da goiabeira 'Pedro Sato' sob diferentes épocas de poda. Revista Brasileira Fruticultura v.29, n.1, p.20-24, 2007. https://doi.org/10.1590/S010029452007000100007.

Instituto Brasileiro de Geografia e Estatística - IBGE. Produção Agrícola 2019. https://sidra.ibge.gov.br. 28 Nov. 2020.

Landau, E.C.; Martins, J.L.A.; Silva, G.A. da. Evolução da produção de goiaba (Psidium guajava, Myrtaceae). In: Landau, E. C.; Silva, G. A. da; Moura, L.; Hirsch, A.; Guimaraes, D. P. (Eds.). Dinâmica da produção agropecuária e da paisagem natural no Brasil nas últimas décadas: produtos de origem vegetal. Brasília: Embrapa, 2020. v.2, p. 839-866. https://ainfo.cnptia.embrapa.br/digital/ bitstream/item/214955/1/LivroDinamicaAgropecBR-Vol02.pdf. 07 Dec. 2020. 
Manica, I.; Icuma, I.M.; Junqueira, N.T.V.; Salvador, J.O.; Moreira, A.; Malavolta, E. Fruticultura tropical 6. Goiaba. Porto Alegre: Cinco Continentes, 2000. 374p.

Martins, F.B.; Ferreira, M.C; Silva, L.F.O; Ramalho, V.R.M; Gonçalves, E.D. Temperatura do ar no desenvolvimento reprodutivo de cultivares de oliveira. Revista Brasileira de Meteorologia, v.34, n.2, p.179-190, 2019. https://doi.org/10.1590/0102-77863340022.

Martins, F.B.; Gonzaga, G.; Santos, D.F.; Reboita, M.S. Classificação climática de Köppen e de Thornthwaite para Minas Gerais: cenário atual e projeções futuras. Revista Brasileira de Climatologia, v.1, p.129-156, 2018. https://doi.org/10.5380/abclima.v1i0.60896.

Mendes, D.S.; Pereira, M.C.T.; Nietsche, S.; Silva, J.F.; Rocha, J.S.; Mendes, A.H.; Xavier, H.R.A.; Santos, R.C. Phenological characterization and temperature requirements of Annona squamosa $\mathrm{L}$. in the Brazilian semiarid region. Anais da Academia Brasileira de Ciências, v.89, n.3, suppl., p.2293-2304, 2017. https://doi.org/10.1590/0001-3765201720170205.

Ramos, D.P.; Leonel, S.; Silva, A.C.; Souza, M.E.; Souza, A.P.; Fragoso, A.M. Épocas de poda na sazonalidade, produção e qualidade dos frutos da goiabeira 'Paluma'. Semina: Ciências Agrárias, v.32, n.3, p.909918, 2011. https://doi.org/10.5433/1679-0359.2011v32n3p909.

Ruelland, E.; Zachowski, A. How plants sense temperature. Environmental and Experimental Botany, v.69, n.3, p.225-232, 2010. https://doi.org/10.1016/j.envexpbot.2010.05.011.

Salazar, D.M.; Melgarejo, P.; Martínez, R.; Martínez, J.J.; Hernández, F.; Burguera, M. Phenological growth stages of guava tree (Psidium guava L.). Scientia Horticulturae, v.108, n.2, p.157-161, 2006. https://doi.org/10.1016/j.scienta.2006.01.022.

Santos, C.E.M.; Costa, J.C.F.; Penso, G.A.; Rosado, L.D.S. Goiaba (Psidium guajava L.). In: Epamig (Ed.). 101 culturas - Manual de tecnologias agrícolas. 2.ed. Belo Horizonte: Epamig, 2019. p.447-458.

Serrano, L.A.L.; Marinho, C.S.; Lima, I.M.; Martins, M.V.V.; Ronchi, C.P.; Tardin, F.D. Fenologia da goiabeira 'Paluma' sob diferentes sistemas de cultivos, épocas e intensidades de poda de frutificação. Bragantia, v.67, n.3, p.701-712, 2008c. https://doi. org/10.1590/S0006-87052008000300019.
Serrano, L.A.L.; Marinho, C.S.; Silva, M.G.e; Tardin, F.D. Características fenológicas e produtivas da goiabeira 'Paluma' podada em diferentes épocas e intensidades no norte fluminense. Revista Ceres, v.55, n.5, p.416-424, 2008b. http://ainfo.cnptia.embrapa. $\mathrm{br} /$ digital/bitstream/item/66831/1/Caracteristicas-fenologicas. pdf. 05 Nov. 2020.

Serrano, L.A.L.; Martins, M.V.V.; Lima, I.M.; Marinho, C.S.; Tardin, F.D. Épocas e intensidades de poda de frutificação na goiabeira 'Paluma', em Pinheiros-ES. Revista Brasileira de Fruticultura, v.30, n.4, p.994-1000, 2008a. https://doi.org/10.1590/S010029452008000400026.

Silva, L.V.; Reis, F.Y.S.; Martins, F.B.; Cassemiro, J.M. Desenvolvimento Vegetativo de Cesalpinea ferrea e Anadenanthera macrocarpa: I - Estimativa das Temperaturas Cardinais. Revista Brasileira de Meteorologia, v.35, n.1, p.23-33, 2020. https://doi. org/10.1590/0102-7786351006.

Singh \& Singh, 2007;

Singh, K.K. A review: Macro-propagation of guava (Psidium guajava). Journal of Pharmacognosy and Phytochemistry, v.7, n.2, p.26292634, 2018. https://www.phytojournal.com/archives/?year=201 8\&vol=7\&issue=2\&Articleld=3874. 07 Dec. 2020.

Singh, V.K.; Ravishankar, H.; Singh, A.; Soni, M.K. Pruning in guava (Psidium guajava) and appraisal of consequent flowering phenology using modified $\mathrm{BBCH}$ scale. Indian Journal of Agricultural Science, v.85, n.11, p.1472-1476, 2015. https:// www.researchgate.net/publication/284237811. 05 Nov. 2020.

Singh, V.K.; Singh, G. Photosynthetic efficiency, canopy micro climate and yield of rejuvenated guava trees. Acta Horticulturae, v.735, p.249-57, 2007. https://doi.org/10.17660/ ActaHortic.2007.735.33.

Uhlmann, L.O.; Streck, N.A.; Becker, C.C.; Schwab, N.T.; Benedetti, R.P.; Charão, A.S.; Ribeiro, B.S.M.R.; Silveira, W.B.; Beckes, F.A.A.L.; Alberto, C.M.; Muttoni, M.; Paula, G.M.; Tomiozzo, R.; Bosco, L.C.; Becker, D. PhenoGlad: A model for simulating development in Gladiolus. European Journal of Agronomy, v.82, part A, p.3349, 2017. https://doi.org/10.1016/j.eja.2016.10.001. 